\title{
Pure Procrastination Scale e Irrational Procrastination Scale: Validation of a Brazilian Version
}

\author{
Roberta Zanini da Rocha ${ }^{1}$ \\ Carla Regina Santos Almeida ${ }^{1}$ \\ Ana Cristina Garcia Dias ${ }^{1}$ \\ ${ }^{1}$ Universidade Federal do Rio Grande do Sul, Porto Alegre, Rio Grande do Sul, Brasil
}

\begin{abstract}
This study aimed to adapt and validate the Irrational Procrastination Scale (IPS) and Pure Procrastination Scale (PPS) for Brazilian Portuguese. Therefore, 2666 university students were invited to participate in the study $(\mathrm{M}=26.08 ; \mathrm{SD}=6.6 ; 77 \%$ female). The factorial structures were analyzed through exploratory and confirmatory factor analyses. The validity was investigated through Pearson's correlations between the subscales of the Academic Procrastination Questionnaire - Negative Consequences and DASS-21. The reliability of the scales and their factors were evaluated through Cronbach's alpha. The results indicated a one-dimensional IPS structure and a three-factor solution with a higher-order factor for PPS. Significant correlations were found between the IPS and PPS with the other measurements, revealing concurrent and convergent validity for both scales. The instruments showed good internal consistency, with alphas ranging from 0.80 to 0.91 .

Keywords: procrastination; scale; validity; measurement; psychological properties.
\end{abstract}

\section{Pure Procrastination Scale e Irrational Procrastination Scale: Validação da Versão Brasileira}

\begin{abstract}
Resumo
O objetivo desse estudo foi adaptar e validar a Irrational Procrastination Scale (IPS) e a Pure Procrastination Scale (PPS) para o português brasileiro. Participaram 2.666 estudantes universitários, alunos de graduação e pós-graduação $(M=26,08$ anos; $D P=$ 6,$6 ; 77 \%$ do sexo feminino). As estruturas fatoriais foram verificadas por análises fatoriais exploratórias e confirmatórias. As evidências de validade foram investigadas por correlações de Pearson entre os instrumentos e as subescalas do Questionário de Procrastinação Acadêmica - Consequências Negativas e a DASS-21. A fidedignidade foi avaliada pelo alfa de Cronbach. Os resultados indicaram uma estrutura unidimensional para a IPS e uma solução de três fatores com um fator geral, de ordem superior, para a PPS. Correlações significativas, de magnitudes entre baixas a altas, foram encontradas entre a IPS e PPS e os demais instrumentos, revelando evidências de validade. Os instrumentos demonstraram boa consistência interna, com alfas variando entre 0,80 a 0,91 .
\end{abstract}

Palavras-chave: procrastinação, escala, validade, avaliação, propriedades psicométricas.

\section{Pure Procrastination Scale and Irrational Procrastination Scale: Validación de la Versión Brasileña}

\begin{abstract}
Resumen
El objetivo de este estudio fue adaptar y validar la Irrational Procrastination Scale (IPS) y la Pure Procrastination Scale (PPS) para el portugués brasileño. Participaron 2.666 estudiantes de pregrado y postgrado ( $M=26,08$ años; DS = 6,6; 77\% mujeres). Las estructuras factoriales fueron analizadas mediante análisis factoriales exploratorios y confirmatorios. Las evidencias de validez fueron investigadas por correlaciones de Pearson entre los instrumentos y subescalas del Cuestionario de Procrastinación Académica - Consecuencias Negativas y DASS-21. La confiabilidad se evaluó con el Alfa de Cronbach. Los resultados indicaron una estructura unidimensional para la IPS y una solución de tres factores con un factor general de segunda orden para la PPS. Se encontraron correlaciones significativas con los otros instrumentos utilizados, revelando evidencias de validez de las escalas. Los instrumentos mostraron una buena consistencia interna, con alfas entre 0,80 y 0,91 .

Palabras clave: procrastinación; escala; validez; evaluación; propiedades psicométricas.
\end{abstract}

\section{Introduction}

Unnecessary task delay may be considered a behavior inherent to human beings (Steel, 2012; Van Eerde, 2003). When this dysfunctional behavior becomes chronic or habitual and has negative consequences for individuals, it is called procrastination (Steel \& Klingsieck, 2016) and may harm them in different spheres, including social, psychological, physical, affective, labor, economic, and academic (Klingsieck, 2013). In particular, the reverberations of personal well-being stand out since procrastination has been associated with higher mental suffering (Van Eerde \& Klingsieck, 2018) and subjectively negative experiences, such as guilt and shame (Martinčeková \& Enright, 2018). The impact of this phenomenon on people's lives has been widely studied since the 1970s (Burka \& Yuen, 2008). The advance in its understanding was driven by constructing 
and refining instruments that accurately measure this construct (Ferrari, Johnson, \& McCown, 1995).

In Brazil, few instruments are available to study the phenomenon, with only four scales identified in searches carried out in the SciELO, PePSIC, Google Scholar, Periódicos CAPES, BVS, and Index Psi databases in July 2019. In this search, the descriptors used were "procrastination" combined with "scale," "measure," and "instrument" written in Portuguese, Spanish, and English. Among the identified instruments, one measures "active procrastination," which is a phenomenon where the individual deliberately postpones a task in order to work better under pressure (Chu \& Choi, 2005). However, Steel and Klingsieck (2016) do not consider this phenomenon a type of procrastination since it may be viewed as a functional, planned, and beneficial strategy.

The other three scales identified in the search aim to investigate the procrastination that occurs specifically in the academic context. The "Escala de Procrastinação Acadêmica" assesses two dimensions: procrastination in daily academic activity and procrastination while studying for exams (Sampaio, 2011). The "Escala de Motivos da Procrastinação Acadêmica" (Geara, Hauck Filho, \& Teixeira, 2017), in turn, assesses two factors related to the reasons for procrastination: lack of motivation and anxiety. The "Questionário de Procrastinação Acadêmica Consequências Negativas" (QPROAC - CN) seeks to assess the perception of university students about possible negative impacts of academic procrastination (Geara \& Teixeira, 2017).

There is a reduced number of instruments available to evaluate procrastination in Brazil. Moreover, despite having good psychometric properties, the available scales are different from those used in other countries. As a result, it is impossible to compare data found in Brazil with those produced by international research since different measures are used in each context (Cassepp-Borges, Balbinotti, \& Teodoro, 2010). Therefore, this study aims to adapt, for the Brazilian context, two instruments regarding procrastination: Pure Procrastination Scale (PPS) and Irrational Procrastination Scale (IPS) (Steel, 2010), and verify the factorial structures of both scales and its evidence of validity.

These instruments, in addition to being extensively used internationally (Steel, 2010; Rebetez, Rochat, Gay, \& Van der Linden, 2014; Rozental et al., 2014; Svartdal, 2015; Svartdal et al., 2016; Svartdal \& Steel, 2017), have already been adapted for eleven other countries and showed promising results, maintaining the appropriate indices for each scale. Thus, it is clear that the instruments are satisfactorily suited to a wide variety of cultures.

The IPS was created in order to evaluate the irrational aspect of procrastination (Steel, 2002). It is a unidimensional scale composed of items that focus on procrastination at the goal implementation stage (Svartdal \& Steel, 2017). The PPS consists of three dimensions and 12 items that indicate a broader understanding of delays related to procrastination and assesses the procrastination patterns in the decision-making and implementation stages, providing information on punctuality and readiness regarding achieving goals.

This scale was developed from a meta-analytical study conducted by Steel (2010) to evaluate instruments on procrastination available in the literature up to that moment. It was composed of three items of the Decisional Procrastination Questionnaire - DPQ (Mann, 1982), five items of the General Procrastination Scale - GPS (Lay, 1986), and four items of the Adult Inventory of Procrastination - AIP (McCown, Johnson, \& Petzel, 1989). Preliminarily, the scale was considered a unidimensional measure that ranked procrastination dysfunctionality. The correlation between IPS and PPS was 0.96 , with the scales being considered parallel methods to evaluate procrastination (Steel, 2010). However, subsequent studies (Rebetez et al., 2014; Rozental et al., 2014; Svartdal et al., 2016; Svartdal \& Steel, 2017) attested that the PPS may present a different structure than the one proposed by Steel (2010).

In the adaptation of the French version of PPS (Rebetez et al., 2014), the scale presented a two-factor structure with a higher-order factor (RMSEA $=0.08$; SRMR $=0.06$; CFI $=0.94)$. Additionally, item 12 was excluded because it had a floor effect and lower itemtotal correlation than the average from other items. The IPS was not adapted to be used in France. The Swedish version of the PPS (Rozental et al., 2014) also has a two-factor structure and was selected when considering the average of commonality, the scree plot analysis, the number of items per factor, cross-loadings, and the number of suggested factors. The IPS maintained its unidimensionality. Adaptation for use in Norway (Svartdal, 2015) resulted in one-factor structures for both IPS and PPS, with PPS preserving its 12 items.

An analysis of the two scales in samples from six different European countries was conducted by Svartdal et al. (2016), and a new structure for PPS was proposed: a model of three different, yet related, facets that represent the delays generated by procrastination. 
The first facet corresponds to delays in the decisionmaking phase, the second to delays in action, and the third to delays in meeting deadlines and punctuality. Confirmatory factor analysis was performed to test all the structures previously presented: the unidimensional model identified by Steel (2010); the two-factor structure suggested by Rebetez et al. (2014); the twofactor model proposed by Rozental et al. (2014), and the three-factor structure from Svartdal et al. (2016). The three-factor model presented the best fit for PPS, with CFI $=0.95$, RMSEA $=0.07$, and SRMR $=0.04$.

A more recent study sampled several countries and evaluated IPS and PPS, along with other procrastination scales (Svartdal \& Steel, 2017). One of the studies aimed to investigate the factorial structures of the scales through confirmatory analyses. Again, the three-factor model, proved among the tested models to be the best solution for PPS (CFI $=0.96$, RMSEA $=0.07$, and SRMR $=0.03)$. In order to improve fit indices, item 9 was excluded, and cross-loadings were allowed between factor 3 and item 1 and between item 3 and factor 2 $(\mathrm{CFI}=0.99, \mathrm{RMSEA}=0.04$, and SRMR $=0.01)$.

Previous studies have suggested a multiplicity of plausible factor structures for PPS, with more favorable results for the three-factor model. Thus, this study aims to identify whether the three-factor solution represents the factor structure with the best fit for the Brazilian version of PPS. Regarding the IPS, the investigation aims to verify whether the unidimensionality reflects the best fit for this scale. The correlation between the central items of the PPS and IPS scale will also be assessed, with moderate to high correlations expected. As a result, evidence of convergent validity between factor 2 of PPS and IPS will be verified. Furthermore, correlations with measures that verify the impacts of procrastination, the frequency of its occurrence in academic tasks, and that assess symptoms of stress, anxiety, and depression will be examined."

According to data in the literature (Constantin, English, \& Mazmanian, 2017; Van Eerde, 2003), procrastination is expected to be positively associated with mental distress symptoms. It is also assumed that positive correlations will be found between the magnitude of procrastination (verified by IPS and PPS) and measures that aim to characterize both the perception of the impact of procrastination and the academic tasks most commonly delayed. Although these scales do not assess the same aspect (magnitude, impact, frequency), it is assumed that associations will be found since they share the same latent trait (procrastination).

\section{Method}

\section{Participants}

The total sample $(\mathrm{N}=2666)$ comprises data collected in two stages to verify the structure and reliability of the scales. The evidence of concurrent validity was made from the partial sample $(\mathrm{N}=1315)$, which is linked to the first stage of the study. Respondents in the total sample were aged between 18 and 67 years $(\mathrm{M}=$ $26.08, \mathrm{SD}=6.6)$, female $(77 \%)$, and undergraduate students $(57.2 \%)$ in public education institutions $(80.3 \%)$. The sample of the second stage has a similar profile, and participants were aged between 18 and 67 years $(\mathrm{M}$ $=26.17, \mathrm{SD}=6.64)$, female $(77.6 \%)$, and undergraduate students $(76.3 \%)$ in public education institutions $(56.2 \%)$.

The research participants were enrolled in some academic activity during their participation at the undergraduate, master, doctorate, specialization, or other academic activity levels. Scholars from all areas of knowledge participated, and most were students in the humanities (23.9\%), applied social sciences (19.2\%), and health sciences $(16.6 \%)$.

\section{Measures}

Sample characterization questionnaire: composed of 28 questions about participants' sociodemographic information and academic life (their area of study, institution, year of admission, semester, among others).

Pure Procrastination Scale - PPS (Steel, 2010): composed of 12 items that evaluate general procrastination (e.g., "I often say 'I will do this tomorrow") using a Likert scale from 1 ("very rarely or does not represent me") to 5 ("Very often or always represents me"). Higher scores reveal higher levels of procrastination. In the original version, the scale presents three factors that measure delays in the decision and implementation stage and difficulties concerning punctuality/readiness.

Irrational Procrastination Scale - IPS (Steel, 2010): consists of six items on general procrastination (e.g., "I postpone tasks beyond what is reasonable"), measured using a Likert scale. This scale ranges from 1 ("very rarely or does not represent me") to 5 ("very often or always represents me"), in which higher scores indicate a greater magnitude of procrastination.

Academic Procrastination Questionnaire Negative Consequences (Geara \& Teixeira, 2017): In this study, two of the six scales that compose the instrument were used: Procrastinated Academic Tasks 
(5 items) and General Impact of Procrastination (8 items). Likert scales from 1 ("the sentence is completely false about me") to 5 ("the sentence is completely true about me") were used. Higher scores reflect a greater impact of procrastination or more significant procrastination of certain academic activities. The items on the Academic Tasks scale are evaluated individually. The one-dimensional Impact of Procrastination scale, on the other hand, showed good internal consistency, with an alpha of 0.90 .

Depression, Anxiety, and Stress Scale - DASS 21 (Vignola \& Tucci, 2014): composed of 21 items and three Likert-type subscales that range from 0 ("it does not apply in any way") to 3 points ("it applies a lot or most of the time"), which assess symptoms of depression, anxiety, and stress experienced in the previous week. The subscales have seven items each. In this study, alphas were 0.90 for the stress and anxiety subscales and 0.91 for the depression subscale.

\section{Procedure}

For this study, samples of university students from two phases of an online survey on procrastination and its correlates, using the Survey Monkey platform, were used. In both phases, PPS and IPS were the first instruments presented to participants after the sociodemographic questionnaire. Instrument adaptation followed the procedures suggested by Borsa, Damásio, and Bandeira (2012) and CasseppBorges et al. (2010). After authorization by the author of the scales, translations were carried out by five independent translators, being that only two of them knew the construct and aims of the scales. The authors and other collaborators then reviewed the translations and the versions produced were synthesized into a single version of each scale. Then, three psychological assessment specialists with experience in developing and adapting psychological instruments analyzed the scales. Only one of them had previous knowledge about the construct and experience in the theme. Thus, the experts' suggestions were incorporated. Six individuals representing the target audience (university students) assessed the adequacy of the items. Then, three independent translators carried out the reverse translation of the instruments. The best back-translation items were selected by three judges (different from the ones who performed the backtranslation), with the translated and back-translated versions sent to the author of the scales, who did not suggest any modifications.
Before the general application, a pilot study was carried out with 14 students, in which the complete questionnaire (with all instruments) was applied to assess the clarity and time taken for its completion. The participant suggestions consisted of reducing the total number of items in the questionnaire, as they considered the response time to be very long. Two participants suggested modifications to improve the clarity of the questions. One participant also pointed out the need to include an answer option called "other" in some sociodemographic questionnaire questions. The respondents could mention other conditions not addressed in the available alternatives (housing situation). The participants' suggestions were discussed by the members of the research group, who investigated their pertinence and adequacy to the aims of the study. All suggestions were applied to the final version of the questionnaire.

After making the suggested adjustments and corrections, data collection continued and was conducted on the Survey Monkey platform from September to November 2018. The invitations to participate were made through social networks (Facebook, Twitter, Instagram) and institutional e-mails.

Ethical procedures were adopted, and the Research Ethics Committee from the Psychology Institute of the Federal University of Rio Grande do Sul (UFRGS) approved the research project (No. 2.717.591). The free and informed consent form was made available before filling out the instruments, and all members of the sample agreed to participate in the study.

\section{Data Analysis}

Both scales were submitted to exploratory (EFA) and confirmatory (CFA) factor analysis. A sample of 2666 cases was used for PPS analyses and 2522 cases for IPS analyses.

The suitability of the sample for conducting factor analyses was tested using Bartlett statistics and the Kaiser-Meyer-Olkin test (KMO). The EFA was performed by factoring polychoric correlation matrices since this estimation is considered the most appropriate for ordinal scales (Damásio \& Dutra, 2017). The diagonally weighted least squares (DWLS) method with Promin oblique rotation was used, and the analyses were conducted using the Factor software version 10.8. Parallel analysis and the Kaiser criterion (eigenvalue $>1$ ) were used to check the number of factors to be retained. In EFA, the closeness to unidimensionality assessment was used since the two scales presented 
one-dimension versions. Thus, three indices were evaluated: unidimensional congruence (UniCo), explained common variance (ECV), and mean of item residual absolute loadings (MIREAL). Values greater than 0.95 in the UniCo index, 0.85 in the ECV index, and less than 0.30 in the MIREAL suggest unidimensionality (Ferrando \& Lorenzo-Seva, 2017).

The CFAs were performed in the R software to verify the IPS and PPS factorial models. The "lavaan" (Rosseel, 2012) and "semPlot" (Fox, Nie, \& Byrnes, 2013) packages were used to analyze and create graphic representations, respectively. The DWLS was chosen because it does not assume that the data are continuous (Muthén, Du Toit, \& Spisic, 1997). The models (EFA and CFA) were evaluated using the chi-square $(\chi 2)$, the comparative fit index (CFI), the Tucker-Lewis index (TLI), and the goodness-of-fit index (GFI). Residual estimates of the root mean square error of approximation (RMSE), with their confidence intervals, and the standardized root mean square residual (SRMR) were also considered according to Hooper, Coughlan, and Mullen (2008) and Hu and Bentler (1999).

The reliability of the scales was verified using Cronbach's alpha. Pearson's correlations were performed between the IPS, PPS, and the other measures to obtain evidence of convergent and concurrent validity for the scales. These analyses, along with descriptive statistics, were obtained using the IBM SPSS Statistics 20 software.

\section{Results}

\section{IPS Factor Structure and Reliability}

There were 2522 cases used in EFA. The data demonstrated was adequate in carrying out this analysis $(\mathrm{KMO}=0.90$ and Bartlett's test with $\mathrm{p}<0.001)$. The parallel analysis suggested the extraction of only one factor, and only one factor had an eigenvalue greater than 1 (factor $1=4.393$; factor $2=0.468$ ). This factor explained $89.17 \%$ of the total variance. The analysis of the values generated by the closeness to unidimensionality assessment confirmed the suggestion of only one factor $($ UniCo $=0.99 ; \mathrm{ECV}=0.92$, and MIREAL $=$ $0.20)$. The fit indices identified were RMSEA $=0.088$ $[\mathrm{CI} 90 \%=0.073-0.099] ;$ TLI $=0.99 ; \mathrm{CFI}=0.99$; GFI $=1.00$. Although the RMSEA is slightly above the acceptable (RMSEA $\leq$ 0.08; Pilati \& Laros, 2007), the other indices point to a good fit of the model. Thus, the unidimensional model is adequate.

The CFA was performed with the same 2522-participant sample. The unidimensional model suggested by the EFA and previous studies was tested. The CFA revealed CFI, TLI, and SRMR values that indicated a good fit $(\mathrm{CFI}=0.96$; $\mathrm{TLI}=0.94 ;$ SRMR $=0.03)$. However, the other indices showed a poor fit for this model $\left(\chi^{2}=177,791\right.$, df $=9, \mathrm{p}<0.001$; RMSEA $=$ 0.086 [CI 90\% $=0.075-0.098])$. Considering the number of participants in the analysis, the chi-square test $(\chi 2)$ may have limitations since it is known to reject any model in large samples (Bentler \& Bonett, 1980); therefore, it is not the most reliable fit measure for the investigated sample. Bearing in mind the CFI, TLI, and SRMR values, the model may be considered acceptable. Only the RMSEA value was indicative of a bad fit despite being within the acceptable range. Thus, the one-factor model may be admitted. The factor loads for each item ranged from 0.74 to 0.83 . The items and their respective loads in both EFA and CFA are shown in Table 1. Cronbach's alpha revealed a high internal consistency of the scale $(\alpha=0.91)$, and the average scores of the participants in the scale were $21.6(\mathrm{SD}=5.6)$.

Table 1.

Factor loadings of both the exploratory and confirmatory factor analysis of IPS

\begin{tabular}{lcc}
\hline & Factor loadings \\
\hline Items & EFA & CFA \\
1. Eu adio tarefas além do que é razoável. & .78 & .74 \\
2. Eu frequentemente me arrependo de não começar as tarefas mais cedo. & .83 & .79 \\
3. Existem aspectos da minha vida que eu deixo para depois, mesmo sabendo que não deveria. & .84 & .80 \\
4. Eu adio tanto as coisas que o meu bem-estar ou eficiência são afetados sem necessidade. & .87 & .83 \\
5. Ao final do dia, eu sei que poderia ter utilizado melhor o meu tempo. & .81 & .75 \\
6. Quando eu deveria fazer uma coisa, eu acabo fazendo outra. & .82 & .78 \\
\hline
\end{tabular}

Psico-USF, Bragança Paulista, v. 26, n. 3, p. 507-518, jul./set. 2021 


\section{PPS Factor Structure and Reliability}

The EFA and CFA were performed with 2666 university students. The software suggested three factors, which is in line with the latest empirical and theoretical evidence (Steel, 2010; Svartdal et al., 2016; Svartdal \& Steel, 2017). The results indicated that the sample is adequate to perform the factor analysis, with $\mathrm{KMO}=0.92$ and Bartlett with $\mathrm{p}<0.001$. Two factors had eigenvalue greater than 1 (factor $1=6.82$; factor $2=1.23$; factor $3=0.91)$. However, the parallel analysis suggested the extraction of only one factor, which explains $72.4 \%$ of the total variance. All closeness to unidimensionality assessment indices suggested that the data may be treated unidimensionally (UniCo $=0.97, \mathrm{ECV}=0.86$, and MIREAL $=0.24)$. Nevertheless, the fit indices for a three-factor solution revealed a good fit for this model $(\mathrm{RMSEA}=0.053$ [CI 90\% $=0.045-0.056] ;$ TLI $=$ 0.99; $\mathrm{CFI}=0.99 ; \mathrm{GFI}=1.00)$. The scale items and their respective factor loads are shown in Table 2.

Then, CFA was performed with the same sample and five models were tested: 1) the unidimensional model suggested by the EFA and reported by Steel (2010) and Svartdal (2015); 2) the two-factor model suggested by Rebetez et al. (2014), in which items 1 to 8 compose one factor, and items 9 to 12 compose the second factor. Contrary to what was done in the French study, item 12 was maintained in the analysis since it had a satisfactory factor load; 3) the two-factor model suggested by Rozental et al. (2014), in which items 1 to 3 and 9 to 12 constitute a factor, and items 4 to 8 integrate the second factor; 4) the three-factor model suggested by Svartdal et al. (2015), in which items 1 to 3 correspond to a factor, 4 to 8 integrate a second factor and those from 9 to 12 compose the third factor; and, finally, 5) a three-factor model, consisting of the same factors as the previous model with a general second-order factor. The fit indices found in each of these models are shown in Table 3.

The unidimensional solution has the worst fit among the five tested solutions. The two two-factor models also did not show a good fit. The CFA of the three-factor model and three-factor model with the second-order factor exhibited an acceptable fit and had the best results when compared to the rest.

Nevertheless, considering that item 9 had the worst factor loading (0.36) and was discrepant and much lower than the other loadings, it was excluded, and new CFA were performed for both models of three factors. The fit indices found for these two models were again identical $(\chi 2=434.264, \mathrm{df}=41, \mathrm{p}<0.001$; CFI $=0.96 ;$ TLI $=0.94 ;$ RMSEA $=0.060$ CI 90\% $=0.055$ $-0.065]$; SRMR $=0.03$ ). An improvement in the fit

Table 2.

Factor loadings of the exploratory factor analysis of PPS

\begin{tabular}{|c|c|c|c|}
\hline \multirow[t]{2}{*}{ Items } & \multicolumn{3}{|c|}{ Factors } \\
\hline & 1 & 2 & 3 \\
\hline 1. Eu demoro a tomar decisões até que seja tarde demais. & .99 & & \\
\hline 2. Mesmo depois de tomar uma decisão, eu demoro a colocá-la em prática. & .82 & & \\
\hline 3. Eu perco muito tempo em coisas banais antes de chegar às decisões finais. & .86 & & \\
\hline $\begin{array}{l}\text { 4. Na preparação para alguns prazos, frequentemente perco tempo fazendo } \\
\text { outras coisas. }\end{array}$ & & .54 & \\
\hline $\begin{array}{l}\text { 5. Eu percebo que passo dias sem fazer tarefas simples, que requerem pouco } \\
\text { esforço além de sentar e fazê-las. }\end{array}$ & & .96 & \\
\hline $\begin{array}{l}\text { 6. Eu frequentemente me vejo realizando tarefas que eu já pretendia ter feito } \\
\text { dias antes. }\end{array}$ & & .88 & \\
\hline 7. Com frequência, eu digo "eu farei isso amanhã". & & .89 & \\
\hline 8. Eu geralmente demoro para começar a trabalhar no que tenho que fazer. & & .76 & \\
\hline 9. Eu me vejo ficando sem tempo suficiente. & & & .36 \\
\hline 10. Eu não faço as coisas a tempo. & & & .89 \\
\hline 11. Eu não sou muito bom/boa em cumprir prazos. & & & 1.01 \\
\hline 12. Deixar as coisas para a última hora já me custou dinheiro no passado. & & & .63 \\
\hline
\end{tabular}


indices is noticed after removing item 9. Both solutions of three factors showed acceptable fit. However, when considering theoretical aspects of procrastination scales and measures, we decided to choose the solution with a general procrastination factor and the three specific factors (decisional delay, implemental delay, and lateness/timeliness). The factor loadings in this model varied between 0.61 and 0.89 . The model structure and all factor loadings are presented in Figure 1.

Cronbach's alpha of the PPS revealed a high internal consistency (total $\alpha=0.91$ ). The values found for each of the factors were also adequate: factor 1 (decisional delay) showed $\alpha=0.80$; factor 2 (implemental delay) had $\alpha=0.90$, while factor 3 (lateness/timeliness) revealed $\alpha=0.80$. The mean scores obtained by participants in the general factor (pure procrastination) was $35.9(\mathrm{SD}=9.0 ; 11$ items); in the decisional delay factor,
9.7 ( $\mathrm{SD}=2.8$; three items); in the implemental delay factor, 18.9 ( $\mathrm{SD}=4.7$, five items); and in the lateness / timelinesss factor, $7.2(\mathrm{SD}=3.2$; three items).

\section{Validity evidence}

The validity evidence of the scales was verified based on Pearson's correlations between these and other measures, with which the IPS and PPS should present a relationship compatible with findings reported in the literature. High correlations were expected between the PPS central items (items 4 to 8) and the IPS, with a measure of $r=0.81$ being found. The correlations between IPS, PPS, and each PPS factor with other procrastination (procrastinated tasks and general impact of procrastination) and measures of symptoms of stress, anxiety, and depression are shown in Table 4.

Table 3.

Fit indices of five different PPS models

\begin{tabular}{lccccc}
\hline Modelo & $\chi^{2}(\mathrm{df})$ & RMSEA $($ IC 90\%) & CFI & SRMR & TLI \\
\hline One-factor (Steel) & $2706.314(54)^{*}$ & $0.136(0.131-0.140)$ & 0.739 & 0.076 & 0.681 \\
Two-factor (Rebetez) & $1577.347(53)^{*}$ & $0.104(0.099-0.108)$ & 0.850 & 0.057 & 0.813 \\
Two-factor (Rozental) & $1877.109(53)^{*}$ & $0.114(0.109-0.118)$ & 0.820 & 0.061 & 0.776 \\
Three-factor (Svartdal) & $1050.813(51)^{*}$ & $0.086(0.081-0.090)$ & 0.902 & 0.043 & 0.873 \\
Three-factor with higher-order factor & $1050.813(51)^{*}$ & $0.086(0.081-0.090)$ & 0.902 & 0.043 & 0.873 \\
\hline
\end{tabular}

${ }^{*} \mathrm{p}<0.001$.

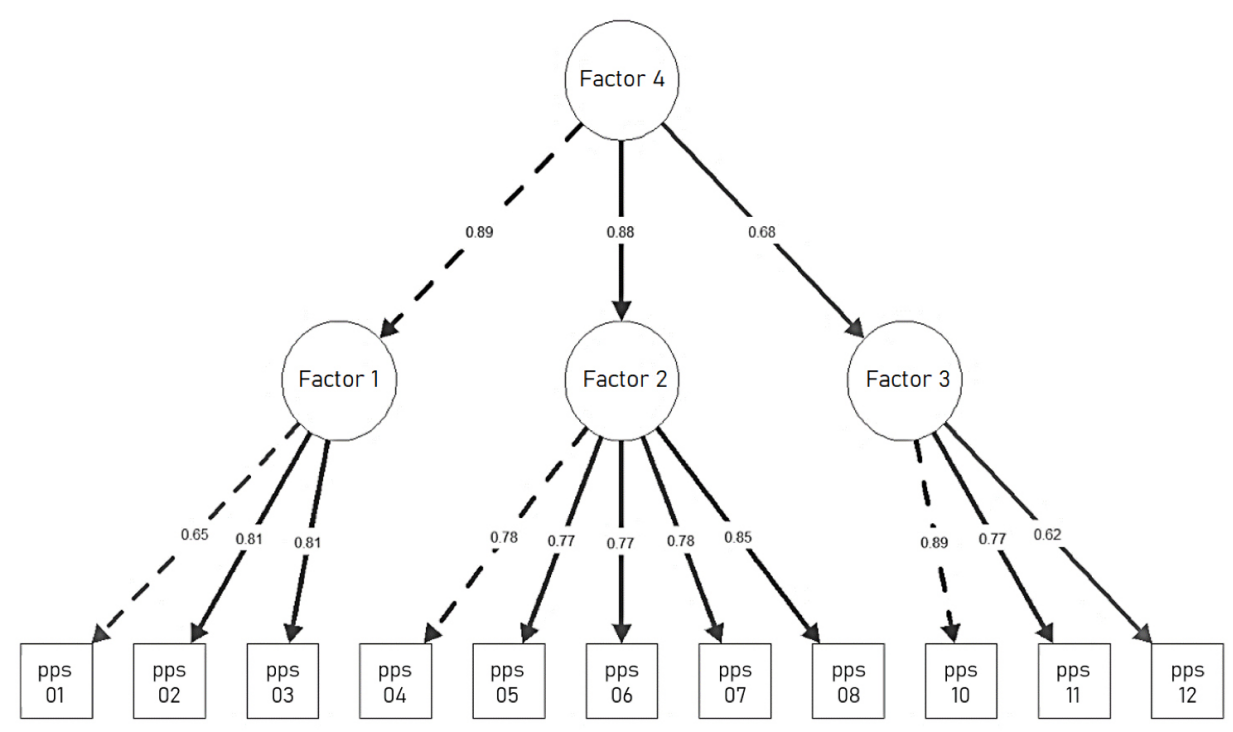

Figure 1. PPS factor structure and loadings 
Average correlations were found with the five procrastinated academic tasks assessed on the "Procrastinated Academic Tasks" scale. Correlations between each of the five items in this scale and both IPS and PPS ranged from 0.32 to 0.60 , and half of them were greater than 0.40 . Stronger correlations with the "Impact of Procrastination" scale, which aimed to assess the impact of this behavior on students' lives, were found. Thus, it does not verify the magnitude of procrastination, as the scales adapted. The correlations found ranged from 0.58 to 0.74 .

Finally, the correlations with the stress, anxiety, and depression dimensions of DASS-21 may be considered weak. Compared to the values reported in the literature, the correlations found in this study are slightly lower. The correlations between the IPS and DASS-21 subscales in this study were between 0.32 and 0.42. Constantin et al. (2017) reported correlations of 0.34 between the IPS and the anxiety subscale of DASS-21 and 0.45 between the IPS and the depression subscale. Gagnon, Dionne, and Pychyl (2016) identified a 0.38 correlation between PPS and all DASS-21 items, and an identical correlation was also found in this study. Regarding reliability, the adapted scales and other instruments used in the study had Cronbach's alpha coefficients greater than 0.80 , as previously presented.

\section{Discussion}

This study aimed to adapt the IPS and PPS scales to Brazilian Portuguese, investigate the factor structure of the scales, and seek further validity evidence indicating the suitability of the instruments for use in Brazil. The fact that the adaptation process was carried out according to Borsa et al. (2012) and Cassepp-Borges et al. (2010) ensures the semantic compatibility of these scales with their original versions. The evaluation of each phase of the process by independent judges and people of the target audience in which the instruments would be applied ensured that the necessary changes were made.

Validity evidence for the adapted version of the instruments was obtained from EFA and CFA and through correlations with procrastination variables. The findings indicated that the scales have good

Table 4.

Correlations among the measures

\begin{tabular}{lcccccccccccccc}
\hline & 1 & 2 & 3 & 4 & 5 & 6 & 7 & 8 & 9 & 10 & 11 & 12 & 13 & 14 \\
\hline 1. IPS & & & & & & & & & & & & & & \\
2. PPS & 0.84 & & & & & & & & & & & & \\
3. PPS 1-3 & 0.68 & 0.82 & & & & & & & & & & & \\
4. PPS 4-8 & 0.81 & 0.90 & 0.65 & & & & & & & & & & \\
5. PPS 10-12 & 0.60 & 0.78 & 0.51 & 0.52 & & & & & & & & & \\
6. Task 1 & 0.49 & 0.50 & 0.40 & 0.51 & 0.32 & & & & & & & & \\
7. Task 2 & 0.44 & 0.45 & 0.34 & 0.43 & 0.35 & 0.49 & & & & & & & \\
8. Task 3 & 0.45 & 0.47 & 0.34 & 0.47 & 0.32 & 0.51 & 0.60 & & & & & & \\
9. Task 4 & 0.43 & 0.44 & 0.35 & 0.42 & 0.32 & 0.39 & 0.55 & 0.65 & & & & & \\
10. Task 5 & 0.57 & 0.60 & 0.45 & 0.58 & 0.46 & 0.47 & 0.50 & 0.53 & 0.60 & & & & \\
11. Impact & 0.74 & 0.72 & 0.58 & 0.64 & 0.59 & 0.49 & 0.41 & 0.41 & 0.38 & 0.53 & & & \\
12. Stress & 0.42 & 0.37 & 0.32 & 0.34 & 0.28 & 0.29 & 0.23 & 0.20 & 0.15 & 0.17 & 0.45 & & \\
13. Anxiety & 0.32 & 0.28 & 0.26 & 0.22 & 0.23 & 0.19 & 0.15 & 0.13 & 0.01 & $0.07 *$ & 0.37 & 0.78 & \\
14. Depression & 0.42 & 0.39 & 0.35 & 0.33 & 0.30 & 0.25 & 0.19 & 0.18 & 0.16 & 0.16 & 0.45 & 0.75 & 0.70 \\
15. DASS-21 & 0.43 & 0.38 & 0.34 & 0.33 & 0.29 & 0.27 & 0.21 & 0.19 & 0.15 & 0.15 & 0.47 & 0.93 & 0.90 & 0.90 \\
\hline
\end{tabular}

PPS 1-3 = Decisional Delay Factor; PPS 4-8 = Implemental Delay Factor; PPS 10 $-12=$ Lateness/Timeliness Factor; Task $1=$ Procrastination of Reading Tasks; Task 2 = Procrastination of Academic Tests; Task 3 = Procrastination of Proffreading of Academic Subjects; Task $4=$ Procrastination of Study for Exams; Task $5=$ Procrastination of Academic Assignments; Impact $=$ General Impact of Procrastination 
psychometric characteristics. The factor structure found for the IPS was unidimensional, which is in line with the results of other studies where the instrument's structure was investigated (Steel, 2010; Svartdal, 2015; Svartdal et al., 2016; Svartdal \& Steel, 2017). Regarding the PPS, different structures for this instrument have been proposed in the literature since different procedures were performed, and models were investigated in the search for a better factor solution of the scale.

A three-factor with a higher order factor comprised the PPS factor structure in this study. Bearing in mind that each of these factors can identify the occurrence of a delay in specific stages of the search for goals (decision making, action implementation, and readiness), it is clear that all of them evaluate procrastination. Therefore, it is plausible that the sum of all items reflects what Steel (2010) called "pure procrastination." Furthermore, the EFA results indicated that it would be appropriate to treat the scale unidimensionally. From this solution, which has a general factor, the scale can be assessed through the results of each of its three factors individually and, at the same time, through a total score, as a unidimensional measure of procrastination.

Still, the scales examined also presented further evidence of validity. Although the instruments used to perform the scales' validity analysis do not seek to measure the same aspect of procrastination (magnitude), the correlations found indicated that they share the same latent trait. The correlations between IPS, PPS, and the three dimensions of DASS-21 were weak despite being similar to the correlations found in previous studies (Constantin et al., 2017; Flett, Haghbin, \& Pychyl, 2016; Gagnon et al., 2016; Van Eerde, 2003). The reproduction of previous findings on the association between procrastination and anxiety, stress and depression is an indicator of the instruments' validity.

\section{Conclusions}

The findings of this study about the validity of the Pure Procrastination Scale and Irrational Procrastination Scale corroborate other studies of adaptation and evaluation of the instruments. The use of these scales makes it possible to compare Brazilian research data with international research findings. From this, the cultural specificities of procrastination in the Brazilian context can be identified in future studies and compared to other similar studies. Furthermore, considering the instruments' brief and straightforward nature, they can be used in large-scale studies in which several scales are applied simultaneously.

Nevertheless, it is essential to note that the validity of the scales was verified only in a university student sample. Acknowledging that the adapted instruments refer to general procrastination and not just to what happens in academic environments, future studies should investigate the measure's validity in the general population. Additional analyses regarding the scales' structure, especially the PPS, must be performed to identify modifications that may lead to a better fit. The invariance of the scales in different groups must also be investigated.

When using these instruments, it is imperative to consider a limitation: the procrastination measures are influenced by the individual's understanding of procrastination, even though the phenomenon is presented before the instrument is applied. One person's understanding of "procrastination" may be interpreted differently by another (Svartdal \& Steel, 2017). Moreover, other factors interfere with the interpretation of procrastination itself, including low self-esteem, anxiety, depression, perfectionism, among others. Therefore, the reported procrastination indices may be due to other aspects and not just the action of delaying tasks (Steel, Brothen, \& Wambach, 2001). It is recommended that such measures be complemented with other related variables, such as the clinical evaluation of behavioral procrastination patterns, when possible.

Finally, the constitution of the sample itself is also a limitation of this study. It is possible that more procrastinating students were interested in participating in the study than those who do not have as many difficulties in carrying out tasks ahead of time. Participants in the study by Geara and Teixeira (2017) reported that they answered the questionnaire while procrastinating another task. As a result, a sample bias may have occurred, in which students who showed interest in participating did so because they experience the negative consequences produced by high levels of procrastination.

\section{References}

Bentler, P. M. \& Bonnet, D. C. (1980). Significance Tests and Goodness of Fit in the Analysis of Covariance Structures. Psychological Bulletin, 88(3), 588-606. doi:10.1037/0033-2909.88.3.588

Borsa,J.C.,Damásio, B.F., \&Bandeira,D.R. (2012). Adaptação e validação de instrumentos psicológicos entre 
culturas: algumas considerações. Paidéia, 22(53), 423-432. doi:10.1590/1982-43272253201314

Burka, J. B., \& Yuen, L. M. (2008). Procrastination: Why You Do It, What to Do about It Now. Cambridge, MA: Da Capo Press.

Cassepp-Borges, V., Balbinotti, M. A. A., \& Teodoro, M.L.M. (2010). Tradução e validação de conteúdo: Uma proposta para a adaptação de instrumentos. Em L. Pasquali (Org.). Instrumentação psicológica: Fundamentos e práticas (pp. 506- 520). Porto Alegre: Artmed.

Chu, A. H., \& Choi, J. N. (2005). Rethinking procrastination: positive effects of " active" procrastination behavior on attitudes and performance. The Journal of Social Psychology, 145(3), 245-264. doi:10.3200/ socp.149.2.195-212

Constantin, K., English, M. M., \& Mazmanian, D. (2017). Anxiety, Depression, and Procrastination Among Students: Rumination Plays a Larger Mediating Role than Worry. Journal of Rational-Emotive \& Cognitive-Behavior Therapy, 36(1), 15-27. doi:10.1007/ s10942-017-0271-5

Damásio, B. F., \& Dutra, D. F. (2017). Análise fatorial exploratória: um tutorial com o software Factor. Em B. F. Damásio \& J. C. Borsa (Eds.). Manual de desenvolvimento de instrumentos psicológicos. (pp. 241265). São Paulo: Vetor.

Ferrando, P. J., \& Lorenzo-Seva U. (2017). Assessing score determinacy, measurement quality, and closeness to unidimensionality in exploratory item factor analysis. Educational and Psychological Measurement, 78(5), 1-19. doi:10.1177/0013164417719308

Ferrari, J. R., Johnson, J. L., \& McCown, W. G. (1995). The Plenum series in social/clinical psychology. Procrastination and task avoidance: Theory, research, and treatment. New York: Plenum Press. doi:10.1007/978-1-4899-0227-6

Fox, J., Nie, Z., \& Byrnes, J. (2013). sem: Structural equation models (R. package version 3.1-1). Disponível: http://CRAN.R-project.org/ package $=$ sem

Flett, A. L., Haghbin, M., \& Pychyl, T. A. (2016). Procrastination and depression from a cognitive perspective: An exploration of the associations among procrastinatory automatic thoughts, rumination, and mindfulness. Journal of
Rational-Emotive \& Cognitive-Behavior Therapy, 34(3), 169-186. doi:10.1007/s10942-016-0235-1

Gagnon, J., Dionne, F., \& Pychyl, T. A. (2016). Committed action: An initial study on its association to procrastination in academic settings. Journal of Contextual Behavioral Science, 5(2), 97-102. doi:10.1016/j. jcbs.2016.04.002

Geara, G. B., Hauck Filho, N., \& Teixeira, M. A. P. (2017). Construção da escala de motivos da procrastinação acadêmica. Psico (PUCRS), 48(2), 140-151. doi:10.15448/1980-8623.2017.2.24635

Geara, G. B., \& Teixeira, M. A. P. (2017). Questionário de Procrastinação Acadêmica-Consequências negativas: propriedades psicométricas e evidências de validade. Avaliação Psicológica, 16(1), 59-69. doi:10.15689/ap.2017.1601.07

Guilera, G., Barrios, M., Penelo, E., Morin, C., Steel, P., \& Gómez-Benito, J. (2018). Validation of the Spanish version of the Irrational Procrastination Scale (IPS). Plos One, 13(1). doi:10.1371/journal. pone.0190806

Hooper, D., Coughlan, J., \& Mullen, M. R. (2008). Structural Equation Modelling: Guidelines for Determining Model Fit. Electronic Journal of Business Research Methods, 6(1), 53-60. Recuperado de http://www.ejbrm.com/issue/download. html?idArticle $=183$

Hu, L. T. \& Bentler, P. M. (1999). Cutoff Criteria for Fit Indexes in Covariance Structure Analysis: Conventional Criteria Versus New Alternatives. Structural Equation Modeling, 6(1), 1-55. doi:10.1080/10705519909540118

Klingsieck, K. B. (2013). Procrastination in different life-domains: is procrastination domain specific? Current Psychology, 32(2), 175-185. doi:10.1007/ s12144-013-9171-8

Lay, C. H. (1986). At last, my research article on procrastination. Journal of Research in Personality, 20(4), 474-495. doi:10.1016/0092-6566(86)90127-3

Mann, L. (1982). Decision-making scale. Em J.R. Ferrari, J. Johnson, \& W. McCown (1995). Procrastination and task avoidance: Theory, research, and treatment. New York: Plenum Press.

Martinčeková, L., \& Enright, R. D. (2018). The effects of self-forgiveness and shame-proneness on procrastination: exploring the mediating role of

Psico-USF, Bragança Paulista, v. 26, n. 3, p. 507-518, jul./set. 2021 
affect. Current Psychology, 39, 428-437. doi:10.1007/ s12144-018-9926-3

McCown, W., Johnson, J., \& Petzel, T. (1989). Procrastination, a principal components analysis. Personality and Individual Differences, 10(2), 197-202. doi:10.1016/0191-8869(89)90204-3

Muthén, B., Du Toit, S. H., \& Spisic, D. (1997). Robust inference using weighted least squares and quadratic estimating equations in latent variable modelling with categorical and continuous outcomes. Psychometrika, 75(1), 1-45. Recuperado de https://www. scienceopen.com $/$ document?vid $=3$ bff $81 \mathrm{df}-62 \mathrm{dd}-$ -494b-afb8-292d541da6a5

Pilati, R., \& Laros, J. A. (2007). Modelos de equações estruturais em psicologia: conceitos e aplicações. Psicologia: Teoria e Pesquisa, 23(2), 205 - 216. doi:10.1590/S0102-37722007000200011

Rebetez, M. M. L., Rochat, L., Gay, P., \& Van der Linden, M. (2014). Validation of a French version of the Pure Procrastination Scale (PPS). Comprehensive Psychiatry, 55(6), 1442-1447. doi:10.1016/j. comppsych.2014.04.024

Rosseel, Y. (2012). Lavaan: An R package for structural equation modeling and more. Version 0.5-12 (BETA). Journal of Statistical Software, 48(2), 1-36. doi:10.18637/jss.v048.i02

Rozental, A., Forsell, E., Svensson, A., Forsström, D., Andersson, G., \& Carlbring, P. (2014). Psychometric evaluation of the Swedish version of the pure procrastination scale, the irrational procrastination scale, and the susceptibility to temptation scale in a clinical population. BMC Psychology, 2(54), 1-12. doi:10.1186/s40359-014-0054-z

Sampaio, R. K. N. (2011). Procrastinação acadêmica e a autorregulação da aprendizagem em estudantes universitários. (Dissertação de Mestrado não publicada). Faculdade de Educação da Universidade Estadual de Campinas, Campinas, Brasil. Recuperado de http://repositorio.unicamp.br/jspui/handle/ REPOSIP/251142

Steel, P. (2002). The measurement and nature of procrastination. (Tese de doutorado não publicada). Faculty of the Graduate School of University of Minnesota, Minnesota, Estados Unidos da América. Recuperado de https://www.researchgate.net/ publication/33764842_The_Measurement_and_ Nature_of_Procrastination
Steel, P. (2010). Arousal, avoidant and decisional procrastinators: Do they exist? Personality and Individual Differences, 48(8), 926-934. doi:10.1016/j. paid.2010.02.025

Steel, P. (2012). A equação de deixar para depois. Rio de Janeiro: Best Seller.

Steel, P., Brothen, T., \& Wambach, C. (2001). Procrastination and personality, performance, and mood. Personality and Individual Differences, 30(1), 95-106. doi:10.1016/S0191-8869(00)00013-1

Steel, P., \& Klingsieck, K. B. (2016). Academic procrastination: Psychological antecedents revisited. Australian Psychologist, 51(1), 36-46. doi:10.1111/ ap.12173

Svartdal, F. (2015). Measuring procrastination: Psychometric properties of the Norwegian versions of the Irrational Procrastination Scale (IPS) and the Pure Procrastination Scale (PPS). Scandinavian Journal of Educational Research, 61(1), 18-30. doi:10.1080 /00313831.2015.1066439

Svartdal, F., Pfuhl, G., Nordby, K., Foschi, G., Klingsieck, K. B., Rozental, A., Carlbring, P., Lindblon-Ylänne, S., \& Rębkowska, K. (2016). On the measurement of procrastination: Comparing two scales in six European countries. Frontiers in Psychology, 7. doi:10.3389/fpsyg.2016.01307

Svartdal, F., \& Steel, P. (2017). Irrational Delay Revisited: Examining Five Procrastination Scales in a Global Sample. Frontiers in Psychology, 8. doi:10.3389/ fpsyg.2017.01927

Van Eerde, W. (2003). A meta-analytically derived nomological network of procrastination. Personality and Individual Differences, 35(6), 1401-1418. doi:10.1016/S0191-8869(02)00358-6

Van Eerde, W., \& Klingsieck, K. B. (2018). Overcoming procrastination? A meta-analysis of intervention studies. Educational Research Review, 25, 73-85. doi:10.1016/j.edurev.2018.09.002

Vignola, R. C. B., \& Tucci, A. M. (2014). Adaptation and validation of the depression, anxiety and stress scale (DASS) to Brazilian Portuguese. Journal of Affective Disorders, 155, 104-109. doi:10.1016/j. jad.2013.10.031

Recebido em: 24/07/2019

Reformulado em: 02/07/2020

Aprovado em: 24/08/2020 
About the authors:

Roberta Zanini da Rocha - Bachelor's (2016) in Psychology at the Federal University of Health Sciences of Porto Alegre/UFCSPA and obtained her master's degree (2019) in Psychology from the Federal University of Rio Grande do Sul (UFRGS). She is a doctoral student in the same postgraduate program and a member of the Center for Cognitive-Behavioral Research and Interventions (UFRGS). She also works as a clinical psychologist, focusing on the mental health of university students.

ORCID: https://orcid.org/0000-0003-2646-3671

E-mail: robertazrocha@gmail.com

Carla Regina Santos Almeida - Psychologist (Federal University of Sergipe), master's degree and doctoral student in Psychology (Federal University of Rio Grande do Sul). She is a member of the Center for Cognitive-Behavioral Research and Interventions (UFRGS). She is interested in teenagers and university students' mental health, emotional regulation, social skills, and psychometry.

ORCID: https://orcid.org/0000-0001-7152-9276

E-mail: ca.rsalmeida@gmail.com

Ana Cristina Garcia Dias - Bachelor's (1995), teaching licensure (1997), and master's degree (1998) in Psychology from the Federal University of Rio Grande do Sul/UFRGS. She obtained her PhD in Psychology (2003) from the University of São Paulo/USP-SP. Post-Doctorate in Psychology from UFRGS (2009). Associate Professor III at UFRGS, teaching undergraduate Psychology and Postgraduate Psychology. Coordinator of the Center for Cognitive-Behavioral Research and Interventions (UFRGS).

ORCID: https://orcid.org/0000-0003-2312-3911

E-mail: anacristinagarciadias@gmail.com

Contact:

Avenida Ramiro Barcelos, 2600, sala 206, Bairro Santa Cecília

Porto Alegre-RS, Brasil

CEP: 90035-003

Telefone: (51) 3308-5246

Celular: (51) 98233-8882 